\title{
DM1 Phenotype Variability and Triplet Repeat Instability: Challenges in the Development of New Therapies
}

\author{
Stéphanie Tomé and Geneviève Gourdon * \\ Inserm UMR 974, Sorbonne Université, Centre de Recherche en Myologie, Association Institut de Myologie, \\ F-75013 Paris, France; stephanie.tome@inserm.fr \\ * Correspondence: genevieve.gourdon@inserm.fr
}

Received: 24 September 2019; Accepted: 8 January 2020; Published: 10 January 2020

\begin{abstract}
Myotonic dystrophy type 1(DM1) is a complex neuromuscular disease caused by an unstable cytosine thymine guanine (CTG) repeat expansion in the DMPK gene. This disease is characterized by high clinical and genetic variability, leading to some difficulties in the diagnosis and prognosis of DM1. Better understanding the origin of this variability is important for developing new challenging therapies and, in particular, for progressing on the path of personalized treatments. Here, we reviewed CTG triplet repeat instability and its modifiers as an important source of phenotypic variability in patients with DM1.
\end{abstract}

Keywords: myotonic dystrophy; clinic variability; CTG repeat instability

\section{Introduction}

Myotonic dystrophy type 1 (DM1) is a complex disease characterized by multisystemic and variable symptoms [1]. Tremendous progress has been made in recent decades in understanding pathophysiological mechanisms due to expanded CTG repeats, paving the way for new therapeutic developments concomitant with the development of new and powerful therapeutic tools [2]. Preclinical assays for DM1 are underway, exploring all possible approaches, and clinical assays have started or are in the starting blocks [3]. Along with the development of innovative molecular tools to block the disastrous consequences of expanded CTG repeats, the broad clinical spectrum associated with variability in onset and severity of symptoms represents a challenge for patient stratification in order to design future trials.

\section{DM1: Variable from All Sides}

From very early descriptions of the disease, DM1 has been recognized as one of the most variable human disorders, with age at onset ranging from fetal to late-adult age and affecting many tissues and systems [1]. Anticipation is particularly evident among DM1 families and has found its molecular basis with the identification of the dynamic CTG repeat expansion [4]. Since then, various laboratories have attempted to correlate, more or less successfully, CTG repeat length, symptoms severity, clinical features, and the classification of clinical forms. The recent developments of registries and cohort studies have made it possible to better characterize the variability of symptoms in populations, and they are valuable tools for correlation studies [5-15]. A recent systematic study performed by the French DM-scope registry has carefully revisited the classification of the disease forms and identified five subtypes in the broad clinical spectrum (Figure 1 and Table 1) [6,7]. These subtypes correlate with the CTG repeat length (CTG size decreased from congenital form (CDM) to late-onset form) but significant overlaps could be observed, highlighting the variability of DM1. This study confirmed the clinical 
spectrum of DM1 and highlighted the temporal succession of clinical profiles. In addition, sex appears to be an important modifying factor, not only for transmitting the severity of the disease but also for the individual clinical profiles (Table 1) [7].

\begin{tabular}{|c|c|c|c|c|c|}
\hline & CONGENITAL & INFANTILE & JUVENILE & ADULT & LATE-ONSET \\
\hline Age at onset (y=year) & $<1$ month & 1 month-10 y & $>10-20 y$ & $>20-40 y$ & $>40 y$ \\
\hline \multicolumn{6}{|l|}{$\begin{array}{l}\text { CTG repeat size* } \\
\text { (From }>1000 \text { to }>50 \text { CTG) }\end{array}$} \\
\hline \multicolumn{6}{|c|}{ Frequency of DM1 features (\%) } \\
\hline Lower education level & 100 & 67 & 57.7 & 59.5 & 53.4 \\
\hline Facial Dysmorphisms & 82.1 & 61.6 & 46.1 & 35.2 & 25.9 \\
\hline Respiratory insufficiency & 66.1 & 50.3 & 36.3 & 32 & 31.9 \\
\hline Muscle weakness & 49.3 & 42.1 & 39.1 & 45 & 33.8 \\
\hline \multicolumn{6}{|c|}{ Frequency of DM1 features (\%) } \\
\hline Diabetes & 1.2 & 7.2 & 7.7 & 10.8 & 12.1 \\
\hline Obesity & 35.1 & 41.7 & 40.8 & 46.2 & 51.5 \\
\hline Cardiac conduction defects & 32.8 & 45.7 & 40.6 & 50.1 & 55.8 \\
\hline Cataracts & 48.3 & 56.7 & 57 & 72.4 & 78.5 \\
\hline \multicolumn{6}{|c|}{ Frequency of DM1 features (\%) } \\
\hline Severa myotonia & 36.6 & 37.9 & $44.3^{\star \star}$ & 30.7 & 19.8 \\
\hline Dysphagia & 60.8 & 56.9 & 49.2 & 51.7 & 51.6 \\
\hline Gl symptoms & 34.2 & 47.5 & 44.2 & 45.1 & 41.3 \\
\hline Somnolence & 15.2 & 26.2 & 25.9 & 22.1 & 24.3 \\
\hline
\end{tabular}

Figure 1. Clinical characteristics of French myotonic dystrophy type 1 (DM1) cohorts [6]. * The mean of CTG repeat length decreases from congenital to late-onset form. The distribution of CTG repeat size overlaps between clinical forms, suggesting genetic variability (see Table 1). The bold numbers represent the highest frequency of certain DM1 features. ${ }^{* *}$ The frequency of most DM1 features among the five forms of DM1 increases or decreases from congenital to late-onset forms. However, the frequency of dysphagia, gastrointestinal (GI) symptoms, and somnolence is stable between the five clinical subtypes. Myotonia is observed in adult form with the highest frequency $(72.4 \%)$.

Table 1. Genetic characteristics of French DM1 cohorts [7]. SD = standard deviation.

\begin{tabular}{lccccc}
\hline & Congenital & Infantile & Juvenile & Adult & Late-Onset \\
\hline CTG repeat size & $1337(684)$ & $1051(401)$ & $784(369)$ & $610(393)$ & $294(310)$ \\
\hline $\begin{array}{l}\text { Maternal transmission } \\
\text { Mean (SD) }\end{array}$ & $1190(711)$ & $760(376)$ & $668(399)$ & $538(359)$ & $346(340)$ \\
\hline $\begin{array}{l}\text { Paternal transmission } \\
\text { Mean (SD) }\end{array}$ & & & & & \\
\hline
\end{tabular}

The main difficulty in diagnosis lies in the CTG repeat length determination, which becomes difficult for long expansions. Polymerase chain reaction (PCR) amplifications are difficult for a high 
number of CTG repeats, and Southern blotting and triplet-primed (TP)-PCR do not allow accurate CTG number measurements. Although optimized protocols have been developed more recently, precise determination of repeat numbers is limited to $\sim 1000$ CTG repeats [16,17]. In addition, age at the time of diagnosis and somatic instability in the blood are confounding factors that can bias correlation studies [18]. Nevertheless, methods have emerged that provide better estimates of the inherited repeat length and extent of the somatic mosaicism in the blood or available tissues. The use of small-pool-PCR (SP-PCR) developed by Monckton et al. in the 1990s has provided considerable information on somatic instability levels in patients and has helped to refine phenotype-genotype correlations in large populations. There is now evidence to clearly demonstrate that length of the estimated inherited repeat length (ePAL) is strongly correlated with age of onset and is the strongest modifier of disease severity [19-21]. Persistent somatic instability in various tissues during the lifetimes of DM1 patients also has an important role to play. Although it appears to be strongly correlated with ePAL, the level of somatic instability may vary from one patient to another (even for those with a similar repeat length) and represent a quantitative hereditary trait $[19,22]$. This trait may be associated with trans-acting genetic modifiers that start to emerge, such as the MutS homolog 3 gene (MSH3), and with cis-acting factors, such as CTG repeat interruptions (see below).

\section{Variable CTG Repeats and Mechanisms Involved}

\subsection{Intergenerational Instability}

Studies of intergenerational instability in DM1 families have shown that the CTG repeat sequence is highly biased towards expansions in parent-child transmissions, with a low tendency toward contractions. A large pedigree analysis estimated the frequency of contractions at $10 \%$ of paternal transmissions and at 3\% of maternal transmissions [23]. The dynamic of intergenerational instability depends on the sex and the size of the CTG repeats in the transmitting parents. However, the effect of the sex on the behavior of intergenerational CTG repeats depends on the size of the CTG repeats in affected parents. The expanded CTG $<80$ CTG repeat units are unstable, with larger intergenerational expansions during paternal transmissions, consistent with an excess of transmitting grandfathers in DM1 families [24-29]. Interestingly, maternal transmissions lead to larger expansions when the affected mother carries a mutated allele from 80 to 250 CTG repeats, consistent with higher CDM cases after maternal transmissions [26].

It is difficult to accurately estimate the intergenerational CTG repeat size changes in DM1 families due to the somatic mosaicism observed in DM1 patients in most cases. However, few analyses of CTG repeat size distributions in germ cells, human embryonic stem cells (hESCs), and embryos have shown that intergenerational instability occurs during the first states of gametogenesis and the first postzygotic events [18,30-35]. Changes in CTG repeat lengths are already present in spermatozoa and immature oocytes of DM1 patients, suggesting that intergenerational instability occurs mainly during germline cell divisions and/or DNA repairs $[30,33]$. A DM1 mouse model showed that germinal CTG expansions are already present in spermatogonia, indicating that the mechanism of intergenerational instability is independent of the meiosis process [36]. In human samples, the highest rate of contraction is observed in spermatozoa, with a frequency of $14.3 \%$. No reduction was observed in oocytes [33]. This data is consistent with results showing that intergenerational CTG repeat contractions occur more often during paternal transmissions [23]. Large expansions > 1000 CTG repeats were observed in immature and metaphase II oocytes, whereas these large mutated alleles were absent in the sperm of most DM1 males, consistent with the low frequency of paternal transmissions of CDM cases [33,35].

Interestingly, methylation of the sequence located around the expanded repeat might explain, at least in part, the maternal bias for CDM and the transmissions of large expansions. A recent attractive hypothesis has proposed that methylation around the repeats, leading to reduced expression of the SIX5 gene in the DM1 locus, could be detrimental to spermatogonia and may prevent the transmission of large repeat expansions after paternal transmissions [37]. 
Intergenerational CTG repeat instability is also observed in hESCs isolated from the inner cell mass of mature blastocytes at 6-7 days after fertilization. The hESCs with large repeat expansions (>1500 CTG) show a tendency towards contractions, whereas the hESCs with 250 and 410 CTG repeats show an instability bias towards expansions at the earliest passages [34]. A parental age effect on the CTG intergenerational length changes for men, with fewer than 70 CTG repeat tracts, and women with $<250$ units were also observed in a large Costa Rican DM1 cohort [26]. The parental age at conception appeared positively correlated with the CTG repeat length changes across transmissions. Although the DM1 mutation was discovered more than 25 years ago and the technology has been improved, the understanding of the behavior of intergenerational CTG repeats remains complex because of the variability among DM1 patients. This variability is associated with the initial size of the repeat, the age and the sex of patients, and the genetic modifiers of the triplet repeat instability.

\subsection{Somatic Instability}

CTG repeats become unstable in tissues between 13 and 16 weeks of gestation age, with the largest expansion in heart, skin, and muscles, and continue to expand over time [38,39]. The degree of somatic instability is tissue-specific, repeat length-dependent, and age-dependent. Somatic mosaicism observed in blood is highly biased towards expansions and contributes to the progressive nature of the various symptoms in different DM1 ethnic groups [19-21]. The averages of CTG repeat lengths increase over time in DM1 blood samples and depend on the initial sizes of the repeats $[20,40,41]$. Indeed, the largest repeats show the highest somatic mosaicism [40]. Recently, it was shown that the degree of somatic instability is lower in saliva (noninvasive sampling method) than in blood, with the difference being highest in DM1 patients with $>150$ CTG repeats. Interestingly, ePAL in blood or saliva only explains $75 \%$ and $66 \%$ of the variations of the age of onset, respectively, suggesting the role of other modifier factors [42]. Somatic instability may be considered as a beneficial therapeutic target for reducing CTG repeat instability in all affected tissues. Few studies have analyzed the sizes of the repeats between tissues due to reduced accessibility of human tissues. In the 1990s, early data revealed a high degree of heterogeneity in CTG repeat expansions in different tissues by using Southern blotting, with greater CTG repeat lengths in muscles, heart, diaphragm, and testes than blood, cerebellum, spleen, and thymus $[30,39,43]$.

In DM1 hESC cells, the data revealed a stabilization of the repeats after arrest of proliferation and differentiation of cells in osteogenic progenitors, neural progenitors, and keratoma cells [34]. Subsequent studies have also shown a stabilization of triplet repeats in induced pluripotent stem cells (iPSCs) and hESC cells after differentiation [44,45]. The data in stem cells evoke a role in proliferation rates in triplet repeat instability in patients. However, no correlation was discovered between the somatic mosaicism observed in tissues and their proliferative rate. In DM1 mouse models, it was shown that CTG repeats can expand rapidly in nondividing cells, further underlying the role of DNA repair in the process of instability [46,47]. In addition, data in DM1 patients and in various models, such as mouse models, or cells have demonstrated that DNA repairs but also DNA replications, transcriptions, and epigenetic changes, as well as the sizes and purity of CTG repeat expansions, influence the dynamics of CTG repeat instability [48-52]. Each process probably participates in a combinatorial manner with relative efficacy that can vary in different tissues and may participate in the variability observed between DM1 patients.

\section{DM1 Variability and Modifiers}

The identification of genetic modifiers in DM1 patients is an important step in developing new therapies and particularly in advancing personalized treatments. Over the past decade, triplet-primed PCR (TP-PCR), enzymatic digestion, and classic Sanger sequencing have revealed the existence of repeat interruptions in expanded CTG alleles in DM1 individuals [53,54]. CGG, CCG, CTC, and CAG interruptions account for approximately $4-9 \%$ of the DM1 population and are associated with the stabilization of CTG repeat tracts in blood [20,21,51,52,54-58]. Moreover, no intergenerational 
expansion was observed in parental transmissions, supporting a stabilization effect of interruptions on triplet repeat tracts. Recent data have shown that CCG/CGG interrupted repeats play a key role in the progression of DM1 symptoms and the age of onset, leading to a reduction in the severity of the disease and a delay of age onset [21]. However, the numbers, locations, and types of interruptions were not considered in this study. Conventional technologies do not allow analyses of the sequences in the middle of large CTG repeat expansions, and thus induce a loss of information that can bias the interpretation of current data. Single-molecule real-time sequencing developments by Pacific Biosciences will provide new data to fill the gaps in our knowledge. The characterizations of variants should be strongly considered during routine diagnosis to improve prognosis in the DM1 population and should be used in future clinical trials.

Several DM1 mouse models have shown the role of the mismatch repair (MMR) pathway in the dynamic of triplet repeat instability, where the MutSß complex (MSH2-MSH3) plays a key role in the formation of CTG repeat expansions [59-62]. In trinucleotide repeat mouse models, MSH3 expression is an important parameter in the degree of triplet instability and is considered as a limiting factor in this process [59,63-65]. Recent data revealed that MSH3 single-nucleotide polymorphisms are associated with somatic mosaicism rates by potentially modifying MSH3 expression and/or activity in DM1 large cohorts $[66,67]$. In addition, genetic association analyses suggest that MSH3/DHFR three tandem repeat alleles, named 3a alleles, may reduce somatic rates but also delay the onset in DM1 patients [67]. MSH3 is clearly a genetic modifier of somatic instability in DM1 but also in other $\mathrm{CTG} \bullet \mathrm{CAG}$ trinucleotide repeat diseases, suggesting a common mechanism $[66,67]$. A large analysis of the Huntington Disease (HD) cohort revealed a clear association between several polymorphisms within DNA repair genes, such as MSH3, LIG1, FAN1, and MLH1, and the degree of somatic mosaicism, suggesting that LIG1 or FAN1 polymorphisms may also explain the variability in DM1 patients, in addition to the MMR proteins $[68,69]$.

Epigenetic changes were also suggested as modifiers of triplet repeat instability and phenotypic variability within DM1 patients [22,37]. Pyrosequencing data revealed that DNA methylation within the DMPK gene can contribute to phenotypic variability (respiratory parameter and muscle strength), regardless of CTG repeat length [22]. Thus, the epigenome of patients may contribute to the progression of DM1 disorder. However, the environment, including food and air pollution, may affect epigenetic changes and has to be considered in epigenetic analyses [70]. Genomic variants may also affect RNA or proteins, which could explain, in part, the clinical variability observed in DM1 patients. Muscleblind-like splicing regulator 1 (MBNL1) variants have been identified and may be an alternative cause of clinical variability in DM1 [71,72]. The $r s 323622$ polymorphism in MBNL1 has been associated with a more severe phenotype and may explain about $2 \%$ of the variance in disease severity [72].

\section{Concluding Remarks}

Since the discovery of unstable CTG repeats causing DM1, considerable progress has been made in characterizing the dynamics of CTG repeat expansions and their relationship to various aspects of the disease, such as clinical severity, onset, and variability of symptoms. The concomitant development of sophisticated techniques has made it possible to refine the correlation between the size of the repeats and the clinical picture and revealed some of the variability evident in DM1. The identification of genetics and modifiers will progress in the future, and the integration of all parameters should allow for a more accurate prognosis and will facilitate the stratification of patients in future clinical trials.

Funding: This research received no external funding.

Conflicts of Interest: The authors declare no conflict of interest. 


\section{References}

1. Harper, P.S. Myotonic Dystrophy, 3rd ed.; W.B Saunders Company: London, UK; Philadelphia, PA, USA, 2001.

2. Sicot, G.; Gourdon, G.; Gomes-Pereira, M. Myotonic dystrophy, when simple repeats reveal complex pathogenic entities: New findings and future challenges. Hum. Mol. Genet. 2011, 20, R116-R123. [CrossRef]

3. Gonzalez-Alegre, P. Recent advances in molecular therapies for neurological disease: Triplet repeat disorders. Hum. Mol. Genet. 2019, 28, R80-R87. [CrossRef]

4. Harper, P.S.; Harley, H.G.; Reardon, W.; Shaw, D.J. Anticipation in myotonic dystrophy: New light on an old problem. Am. J. Hum. Genet. 1992, 51, 10-16. [PubMed]

5. Chong-Nguyen, C.; Wahbi, K.; Algalarrondo, V.; Bécane, H.M.; Radvanyi-Hoffman, H.; Arnaud, P.; Furling, D.; Lazarus, A.; Bassez, G.; Béhin, A.; et al. Association Between Mutation Size and Cardiac Involvement in Myotonic Dystrophy Type 1. Circ. Cardiovasc. Genet. 2017, 10, e001526. [CrossRef] [PubMed]

6. De Antonio, M.; Dogan, C.; Hamroun, D.; Mati, M.; Zerrouki, S.; Eymard, B.; Katsahian, S.; Bassez, G. Unravelling the myotonic dystrophy type 1 clinical spectrum: A systematic registry-based study with implications for disease classification. Rev. Neurol. 2016, 172, 572-580. [CrossRef] [PubMed]

7. Dogan, C.; de Antonio, M.; Hamroun, D.; Varet, H.; Fabbro, M.; Rougier, F.; Amarof, K.; Arne Bes, M.-C.; Bedat-Millet, A.-L.; Behin, A.; et al. Gender as a Modifying Factor Influencing Myotonic Dystrophy Type 1 Phenotype Severity and Mortality: A Nationwide Multiple Databases Cross-Sectional Observational Study. PLoS ONE 2016, 11, e0148264. [CrossRef] [PubMed]

8. Gagnon, C.; Petitclerc, É.; Kierkegaard, M.; Mathieu, J.; Duchesne, É.; Hébert, L.J. A 9-year follow-up study of quantitative muscle strength changes in myotonic dystrophy type 1. J. Neurol. 2018, 265, 1698-1705. [CrossRef]

9. Heatwole, C.; Bode, R.; Johnson, N.; Quinn, C.; Martens, W.; McDermott, M.P.; Rothrock, N.; Thornton, C.; Vickrey, B.; Victorson, D.; et al. Patient-reported impact of symptoms in myotonic dystrophy type 1 (PRISM-1). Neurology 2012, 79, 348-357. [CrossRef] [PubMed]

10. Jiménez-Moreno, A.C.; Raaphorst, J.; Babačić, H.; Wood, L.; van Engelen, B.; Lochmüller, H.; Schoser, B.; Wenninger, S. Falls and resulting fractures in Myotonic Dystrophy: Results from a multinational retrospective survey. Neuromuscul. Disord. 2018, 28, 229-235. [CrossRef]

11. Johnson, N.E.; Ekstrom, A.-B.; Campbell, C.; Hung, M.; Adams, H.R.; Chen, W.; Luebbe, E.; Hilbert, J.; Moxley, R.T.; Heatwole, C.R. Parent-reported multi-national study of the impact of congenital and childhood onset myotonic dystrophy. Dev. Med. Child Neurol. 2016, 58, 698-705. [CrossRef]

12. Rakocevic-Stojanovic, V.; Peric, S.; Basta, I.; Dobricic, V.; Ralic, V.; Kacar, A.; Peric, M.; Novakovic, I. Variability of multisystemic features in myotonic dystrophy type 1-Lessons from Serbian registry. Neurol. Res. 2015, 37, 939-944. [CrossRef] [PubMed]

13. Vanacore, N.; Rastelli, E.; Antonini, G.; Bianchi, M.L.E.; Botta, A.; Bucci, E.; Casali, C.; Costanzi-Porrini, S.; Giacanelli, M.; Gibellini, M.; et al. An Age-Standardized Prevalence Estimate and a Sex and Age Distribution of Myotonic Dystrophy Types 1 and 2 in the Rome Province, Italy. Neuroepidemiology 2016, 46, 191-197. [CrossRef] [PubMed]

14. Wood, L.; Cordts, I.; Atalaia, A.; Marini-Bettolo, C.; Maddison, P.; Phillips, M.; Roberts, M.; Rogers, M.; Hammans, S.; Straub, V.; et al. The UK Myotonic Dystrophy Patient Registry: Facilitating and accelerating clinical research. J. Neurol. 2017, 264, 979-988. [CrossRef] [PubMed]

15. Wood, L.; Bassez, G.; Bleyenheuft, C.; Campbell, C.; Cossette, L.; Jimenez-Moreno, A.C.; Dai, Y.; Dawkins, H.; Manera, J.A.D.; Dogan, C.; et al. Eight years after an international workshop on myotonic dystrophy patient registries: Case study of a global collaboration for a rare disease. Orphanet J. Rare Dis. 2018, 13, 155. [CrossRef]

16. Malbec, R.; Chami, B.; Aeschbach, L.; Buendía, G.A.R.; Socol, M.; Joseph, P.; Leïchlé, T.; Trofimenko, E.; Bancaud, A.; Dion, V. $\mu$ LAS: Sizing of expanded trinucleotide repeats with femtomolar sensitivity in less than 5 minutes. Sci. Rep. 2019, 9, 23. [CrossRef]

17. Leferink, M.; Wong, D.P.W.; Cai, S.; Yeo, M.; Ho, J.; Lian, M. Robust and accurate detection and sizing of repeats within the DMPK gene using a novel TP-PCR test. Sci. Rep. 2019, 9, 8280. [CrossRef]

18. Monckton, D.G.; Wong, L.J.C.; Ashizawa, T.; Caskey, C.T. Somatic mosaicism, germline expansions, germline reversions and intergenerational reductions in myotonic dystrophy males: Small pool PCR analyses. Hum. Mol. Genet. 1995, 4, 1-8. [CrossRef] 
19. Morales, F.; Couto, J.M.; Higham, C.F.; Hogg, G.; Cuenca, P.; Braida, C.; Wilson, R.H.; Adam, B.; Valle, G.; Brian, R.; et al. Somatic instability of the expanded CTG triplet repeat in myotonic dystrophy type 1 is a heritable quantitative trait and modifier of disease severity. Hum. Mol. Genet. 2012, 21, 3558-3567. [CrossRef]

20. Cumming, S.A.; Jimenez-moreno, C.; Okkersen, K.; Wenninger, S.; Daidj, F.; Hogarth, F.; Littleford, R.; Gorman, G.; Bassez, G.; Schoser, B.; et al. Genetic determinants of disease severity in the myotonic dystrophy type 1 OPTIMISTIC cohort. Neurology 2019, 93, e995-e1009. [CrossRef]

21. Overend, G.; Légaré, C.; Mathieu, J.; Bouchard, L.; Gagnon, C.; Monckton, D.G. Allele length of the DMPK CTG repeat is a predictor of progressive myotonic dystrophy type 1 phenotypes. Hum. Mol. Genet. 2019, 28, 2245-2254. [CrossRef]

22. Overend, G.; Guay, S.; Monckton, D.G.; Mathieu, J.; Gagnon, C.; Bouchard, L. DMPK gene DNA methylation levels are associated with muscular and respiratory profiles in DM1. Neurol. Genet. 2019, 5, e338.

23. Ashizawa, T.; Anvret, M.; Baiget, M.; Barcelo, J.M.; Brunner, H.; Cobo, A.M.; Dallapiccola, B.; Fenwick, R.G., Jr.; Grandell, U.; Harley, H.; et al. Characteristics of intergenerational contractions of the CTG repeat in myotonic dystrophy. Am. J. Hum. Genet. 1994, 54, 414-423. [PubMed]

24. Ashizawa, T.; Dunne, P.W.; Ward, P.A.; Seltzer, W.K.; Richards, C.S. Effects of the sex of myotonic dystrophy patients on the unstable triplet repeat in their affected offspring. Neurology 1994, 44, 120-122. [CrossRef] [PubMed]

25. Brunner, H.G.; Bruggenwirth, H.T.; Nillesen, W.; Jansen, G.; Hamel, B.C.; Hoppe, R.L.; de Die, C.E.; Howeler, C.J.; van Oost, B.A.; Wieringa, B.; et al. Influence of sex of the transmitting parent as well as of parental allele size on the CTG expansion in myotonic dystrophy (DM). Am. J. Hum. Genet. 1993, 53, 1016-1023.

26. Morales, F.; Vasquez, M.; Cuenca, P.; Campos, D.; Santamaria, C.; del Valle, G.; Brian, R.; Sittenfeld, M.; Monckton, D.G. Parental age effects, but no evidence for an intrauterine effect in the transmission of myotonic dystrophy type 1. Eur. J. Hum. Genet. 2015, 23, 646-653. [CrossRef]

27. Lavedan, C.; Hofmann-Radvanyi, H.; Shelbourne, P.; Rabes, J.P.; Duros, C.; Savoy, D.; Dehaupas, I.; Luce, S.; Johnson, K.; Junien, C. Myotonic dystrophy: Size- and sex-dependent dynamics of CTG meiotic instability, and somatic mosaicism. Am. J. Hum. Genet. 1993, 52, 875-883.

28. Harley, H.G.; Rundle, S.A.; MacMillan, J.C.; Myring, J.; Brook, J.D.; Crow, S.; Reardon, W.; Fenton, I.; Shaw, D.J.; Harper, P.S. Size of the unstable CTG repeat sequence in relation to phenotype and parental transmission in myotonic dystrophy. Am. J. Hum. Genet. 1993, 52, 1164-1174.

29. De Munain, A.L.; Cobo, A.M.; Poza, J.J.; Emparanza, J.I.; Baiget, M.; Navarrete, D.; Martorell, L.; Palau, F.; Munain, D. Influence of the sex of the transmitting grandparent in congenital myotonic dystrophy. J. Med. Genet. 1995, 32, 689-691. [CrossRef]

30. Jansen, G.; Willems, P.; Coerwinkel, M.; Nillesen, W.; Smeets, H.; Vits, L.; Howeler, C.; Brunner, H.; Wieringa, B. Gonosomal mosaicism in myotonic dystrophy patients: Involvement of mitotic events in (CTG)n repeat variation and selection against extreme expansion in sperm. Am. J. Hum. Genet. 1994, 54, 575-585.

31. Martorell, L.; Gamez, J.; Cayuela, M.L.; Gould, F.K.; McAbney, J.P.; Ashizawa, T.; Monckton, D.G.; Baiget, M. Germline mutational dynamics in myotonic dystrophy type 1 males: Allele length and age effects. Neurology 2004, 62, 269-274. [CrossRef]

32. Martorell, L.; Monckton, D.G.; Gamez, J.; Baiget, M. Complex patterns of male germline instability and somatic mosaicism in myotonic dystrophy type 1. Eur. J. Hum. Genet. 2000, 8, 423. [CrossRef] [PubMed]

33. De Temmerman, N.; Sermon, K.; Seneca, S.; de Rycke, M.; Hilven, P.; Lissens, W.; Steirteghem, A.; van Liebaers, I. Intergenerational Instability of the Expanded CTG Repeat in the DMPK Gene: Studies in Human Gametes and Preimplantation Embryos. Am. J. Hum. Genet. 2004, 75, 325-329. [CrossRef] [PubMed]

34. Seriola, A.; Spits, C.; Simard, J.P.; Hilven, P.; Haentjens, P.; Pearson, C.E.; Sermon, K. Huntington's and myotonic dystrophy hESCs: Down-regulated trinucleotide repeat instability and mismatch repair machinery expression upon differentiation. Hum. Mol. Genet. 2011, 20, 176-185. [CrossRef] [PubMed]

35. Dean, N.L.; Tan, S.L.; Ao, A. Instability in the transmission of the myotonic dystrophy CTG repeat in human oocytes and preimplantation embryos. Fertil. Steril. 2006, 86, 98-105. [CrossRef] [PubMed]

36. Savouret, C.; Garcia-Cordier, C.; Megret, J.; te Riele, H.; Junien, C.; Gourdon, G. MSH2-dependent germinal CTG repeat expansions are produced continuously in spermatogonia from DM1 transgenic mice. Mol. Cell. Biol. 2004, 24, 629-637. 
37. Barbé, L.; Lanni, S.; López-Castel, A.; Franck, S.; Spits, C.; Keymolen, K.; Seneca, S.; Tomé, S.; Miron, I.; Letourneau, J.; et al. CpG Methylation, a Parent-of-Origin Effect for Maternal-Biased Transmission of Congenital Myotonic Dystrophy. Am. J. Hum. Genet. 2017, 100, 488-505. [CrossRef]

38. Martorell, L.; Johnson, K.; Boucher, C.A.; Baiget, M. Somatic instability of the myotonic dystrophy (CTG)n repeat during human fetal development. Hum. Mol. Genet. 1997, 6, 877-880. [CrossRef]

39. Wörhle, D.; Kennerknecht, I.; Wolf, M.; Enders, H.; Schwemmle, S.; Steinbach, P. Heterogeneity of DM kinase repeat expansion in different fetal tissues and further expansion during cell proliferation in vitro: Evidence for a casual involvement of methyl-directed DNA mismatch repair in triplet repeat stability. Hum. Mol. Genet. 1995, 4, 1147-1153.

40. Martorell, L.; Martinez, J.M.; Carey, N.; Johnson, K.; Baiget, M. Comparison of CTG repeat length expansion and clinical progression of myotonic dystrophy over a five year period. J. Med. Genet. 1995, 32, 593-596. [CrossRef]

41. Martorell, L.; Monckton, D.G.; Gamez, J.; Johnson, K.J.; Gich, I.; de Munain, A.L.; Baiget, M.; de Minain, A.L.; Baiget, M. Progression of somatic CTG repeat length heterogeneity in the blood cells of myotonic dystrophy patients. Hum. Mol. Genet. 1998, 7, 307-312. [CrossRef]

42. Corrales, E.; Vásquez, M.; Zhang, B.; Santamaría-Ulloa, C.; Cuenca, P.; Krahe, R.; Monckton, D.G.; Morales, F. Analysis of mutational dynamics at the DMPK (CTG)n locus identifies saliva as a suitable DNA sample source for genetic analysis in myotonic dystrophy type 1. PLoS ONE 2019, 14, e0216407. [CrossRef] [PubMed]

43. Kinoshita, M.; Takahashi, R.; Hasegawa, T.; Komori, T.; Nagasawa, R.; Hirose, K.; Tanabe, H. (CTG)(n) expansions in various tissues from a myotonic dystrophy patient. Muscle Nerve 1996, 19, 240-242. [CrossRef]

44. Ueki, J.; Nakamori, M.; Nakamura, M.; Nishikawa, M.; Yoshida, Y.; Tanaka, A.; Morizane, A.; Kamon, M.; Araki, T.; Takahashi, M.P.; et al. Myotonic dystrophy type 1 patient-derived iPSCs for the investigation of CTG repeat instability. Sci. Rep. 2017, 7, 42522. [CrossRef] [PubMed]

45. Du, J.; Campau, E.; Soragni, E.; Jespersen, C.; Gottesfeld, J.M. Length-dependent CTG.CAG triplet-repeat expansion in myotonic dystrophy patient-derived induced pluripotent stem cells. Hum. Mol. Genet. 2013, 22, 5276-5287. [CrossRef]

46. Lia, A.S.; Seznec, H.; Hofmann-Radvanyi, H.; Radvanyi, F.; Duros, C.; Saquet, C.; Blanche, M.; Junien, C.; Gourdon, G. Somatic instability of the CTG repeat in mice transgenic for the myotonic dystrophy region is age dependent but not correlated to the relative intertissue transcription levels and proliferative capacities. Hum. Mol. Genet. 1998, 7, 1285-1291. [CrossRef]

47. Gomes-Pereira, M.; Fortune, M.T.; Monckton, D.G. Mouse tissue culture models of unstable triplet repeats: In vitro selection for larger alleles, mutational expansion bias and tissue specificity, but no association with cell division rates. Hum. Mol. Genet. 2001, 10, 845-854. [CrossRef]

48. Usdin, K.; House, N.C.M.; Freudenreich, C.H. Repeat instability during DNA repair: Insights from model systems. Crit. Rev. Biochem. Mol. Biol. 2015, 50, 1549-7798. [CrossRef]

49. Pearson, C.E.; Edamura, K.N.; Cleary, J.D.; Nichol Edamura, K.; Cleary, J.D. Repeat instability: Mechanisms of dynamic mutations. Nat. Rev. Genet. 2005, 6, 729-742. [CrossRef]

50. Dion, V. Tissue specificity in DNA repair: Lessons from trinucleotide repeat instability. Trends Genet. 2014, 30, 220-229. [CrossRef]

51. Tomé, S.; Dandelot, E.; Dogan, C.; Bertrand, A.; Geneviève, D.; Péréon, Y.; Simon, M.; Bonnefont, J.P.; Bassez, G.; Gourdon, G.; et al. Unusual association of a unique CAG interruption in 5' of DM1 CTG repeats with intergenerational contractions and low somatic mosaicism. Hum. Mutat. 2018, 39, 970-982. [CrossRef]

52. Santoro, M.; Masciullo, M.; Silvestri, G.; Novelli, G.; Botta, A. Myotonic dystrophy type 1: Role of CCG, CTC and CGG interruptions within DMPK alleles in the pathogenesis and molecular diagnosis. Clin. Genet. 2017, 92, 355-364. [CrossRef] [PubMed]

53. Warner, J.P.; Barron, L.H.; Goudie, D.; Kelly, K.; Dow, D.; Fitzpatrick, D.R.; Brock, D.J. A general method for the detection of large CAG repeat expansions by fluorescent PCR. J. Med. Genet. 1996, 33, 1022-1026. [CrossRef] [PubMed]

54. Braida, C.; Stefanatos, R.K.A.; Adam, B.; Mahajan, N.; Smeets, H.J.M.; Niel, F.; Goizet, C.; Arveiler, B.; Koenig, M.; Lagier-Tourenne, C.; et al. Variant CCG and GGC repeats within the CTG expansion dramatically modify mutational dynamics and likely contribute toward unusual symptoms in some myotonic dystrophy type 1 patients. Hum. Mol. Genet. 2010, 19, 1399-1412. [CrossRef] [PubMed] 
55. Cumming, S.A.; Hamilton, M.J.; Robb, Y.; Gregory, H.; McWilliam, C.; Cooper, A.; Adam, B.; McGhie, J.; Hamilton, G.; Herzyk, P.; et al. De novo repeat interruptions are associated with reduced somatic instability and mild or absent clinical features in myotonic dystrophy type 1. Eur. J. Hum. Genet. 2018, 26, 1635-1647. [CrossRef]

56. Pešović, J.; Perić, S.; Brkušanin, M.; Brajušković, G.; Rakočević-Stojanović, V.; Savić-Pavićević, D. Molecular genetic and clinical characterization of myotonic dystrophy type 1 patients carrying variant repeats within DMPK expansions. Neurogenetics 2017, 18, 207-218. [CrossRef]

57. Botta, A.; Rossi, G.; Marcaurelio, M.; Fontana, L.; D’Apice, M.R.; Brancati, F.; Massa, R.G.; Monckton, D.; Sangiuolo, F.; Novelli, G. Identification and characterization of $5^{\prime}$ CCG interruptions in complex DMPK expanded alleles. Eur. J. Hum. Genet. 2017, 25, 257-261. [CrossRef]

58. Musova, Z.; Mazanec, R.; Krepelova, A.; Ehler, E.; Vales, J.; Jaklova, R.; Prochazka, T.; Koukal, P.; Marikova, T.; Kraus, J.; et al. Highly unstable sequence interruptions of the CTG repeat in the myotonic dystrophy gene. Am. J. Med. Genet. A 2009, 149A, 1365-1374. [CrossRef]

59. Foiry, L.; Dong, L.; Savouret, C.; Hubert, L.; te Riele, H.; Junien, C.; Gourdon, G. Msh3 is a limiting factor in the formation of intergenerational CTG expansions in DM1 transgenic mice. Hum. Genet. 2006, 119, 520-526. [CrossRef]

60. Van den Broek, W.J.A.A.; Nelen, M.R.; Wansink, D.G.; Coerwinkel, M.M.; te Riele, H.; Groenen, P.J.T.A.; Wieringa, B. Somatic expansion behaviour of the (CTG) $n$ repeat in myotonic dystrophy knock-in mice is differentially affected by Msh3 and Msh6 mismatch-repair proteins. Hum. Mol. Genet. 2002, 11, $191-198$. [CrossRef]

61. Gomes-Pereira, M.; Fortune, M.T.; Ingram, L.; McAbney, J.P.; Monckton, D.G. Pms2 is a genetic enhancer of trinucleotide CAG.CTG repeat somatic mosaicism: Implications for the mechanism of triplet repeat expansion. Hum. Mol. Genet. 2004, 13, 1815-1825. [CrossRef]

62. Savouret, C.; Brisson, E.; Essers, J.; Kanaar, R.; Pastink, A.; te Riele, H.; Junien, C.; Gourdon, G. CTG repeat instability and size variation timing in DNA repair-deficient mice. EMBO J. 2003, 22, 2264-2273. [CrossRef] [PubMed]

63. Dragileva, E.; Hendricks, A.; Teed, A.; Gillis, T.; Lopez, E.T.; Friedberg, E.C.; Kucherlapati, R.; Edelmann, W.; Lunetta, K.L.; MacDonald, M.E.; et al. Intergenerational and striatal CAG repeat instability in Huntington's disease knock-in mice involve different DNA repair genes. Neurobiol. Dis. 2009, 33, 37-47. [CrossRef] [PubMed]

64. Tome, S.; Manley, K.; Simard, J.P.; Clark, G.W.; Slean, M.M.; Swami, M.; Shelbourne, P.F.; Tillier, E.R.; Monckton, D.G.; Messer, A.; et al. MSH3 polymorphisms and protein levels affect CAG repeat instability in Huntington's disease mice. PLoS Genet. 2013, 9, e1003280. [CrossRef] [PubMed]

65. Zhao, X.N.; Kumari, D.; Gupta, S.; Wu, D.; Evanitsky, M.; Yang, W.; Usdin, K. Muts $\beta$ generates both expansions and contractions in a mouse model of the Fragile X-associated disorders. Hum. Mol. Genet. 2015, 24, 7087-7096. [CrossRef]

66. Morales, F.; Vásquez, M.; Santamaría, C.; Cuenca, P.; Corrales, E.; Monckton, D.G. A polymorphism in the MSH3 mismatch repair gene is associated with the levels of somatic instability of the expanded CTG repeat in the blood DNA of myotonic dystrophy type 1 patients. DNA Repair 2016, 40, 57-66. [CrossRef]

67. Flower, M.; Lomeikaite, V.; Ciosi, M.; Cumming, S.; Morales, F.; Lo, K.; Moss, D.H.; Jones, L.; Holmans, P.; Investigators, T.; et al. MSH3 modifies somatic instability and disease severity in Huntington's and myotonic dystrophy type 1 . Brain 2019, 142, 1876-1886. [CrossRef]

68. Lee, J.M.; Wheeler, V.C.; Chao, M.J.; Vonsattel, J.P.G.; Pinto, R.M.; Lucente, D.; Abu-Elneel, K.; Ramos, E.M.; Mysore, J.S.; Gillis, T.; et al. Identification of Genetic Factors that Modify Clinical Onset of Huntington's Disease. Cell 2015, 162, 516-526. [CrossRef]

69. Moss, D.J.H.; Tabrizi, S.J.; Mead, S.; Lo, K.; Pardiñas, A.F.; Holmans, P.; Jones, L.; Langbehn, D.; Coleman, A.; Santos, R.D.; et al. Identification of genetic variants associated with Huntington's disease progression: A genome-wide association study. Lancet Neurol. 2017. [CrossRef]

70. Tiffon, C. The impact of nutrition and environmental epigenetics on human health and disease. Int. J. Mol. Sci. 2018, 19, 3425. [CrossRef]

71. Larsen, M.; Kress, W.; Schoser, B.; Hehr, U.; Müller, C.R.; Rost, S. Identification of variants in MBNL1 in patients with a myotonic dystrophy-like phenotype. Eur. J. Hum. Genet. 2016, 24, 1467-1472. [CrossRef] 
72. Huin, V.; Vasseur, F.; Schraen-Maschke, S.; Dhaenens, C.-M.; Devos, P.; Dupont, K.; Sergeant, N.; Buée, L.; Lacour, A.; Hofmann-Radvanyi, H.; et al. MBNL1 gene variants as modifiers of disease severity in myotonic dystrophy type 1. J. Neurol. 2013, 260, 998-1003. [CrossRef] [PubMed] 